\title{
Development of Refractory Synthesized from Waste Ceramic Fiber and Chamotte
}

\author{
Do Quang Minh ${ }^{1, *}$, Nguyen Vu Uyen Nhi ${ }^{2}$, Nguyen Hoc Thang ${ }^{3, *}$ \\ ${ }^{1}$ Associate Professor, Faculty of Materials Technology, Ho Chi Minh City University of Technology \\ (HCMUT) - Vietnam National University (VNU), Ho Chi Minh City, Viet Nam \\ ${ }^{2}$ Research Scholar and Lecturer, Faculty of Materials Technology, Ho Chi Minh City University of \\ Technology (HCMUT) - Vietnam National University (VNU), Ho Chi Minh City, Viet Nam \\ ${ }^{3} \mathrm{PhD}$. Eng., Faculty of Chemical Technology, Ho Chi Minh City University of Food Industry, Ho Chi \\ Minh City, Viet Nam
}

\begin{abstract}
Research on refractory materials is always essential in thermal engineering to ensure both heat savings and environmental protection. Raw materials used initially have a great influence on the production process and product properties. In addition, the refractory products are tested under conditions of high temperature and varying intensity, such as tests of thermal shock resistance. In this study, new refractory composites were prepared by mixing waste ceramic fibers with chamotte materials and heated at $1220^{\circ} \mathrm{C}$ for 1 hour. The refractory composites have low values of the volumetric weight from 0.87 to $1.32 \mathrm{~g} / \mathrm{cm}^{3}$ which are belong to group oflightweight materials. More important, the strength values of the products are high with testing of bending and compressive strength. Experimental results also showed that the thermal shock resistance of these synthesized materials has high quality in comparison with others referential chamotte refractory materials. Moreover, the coefficient of thermal expansion of the composite is lower than the same types of materials. Analysis of scanning electron microscope image (SEM) shows that the ceramic fiber distribution in the material has the effect of preventing the development of cracks. The material has been applied as resistors, hot gas pipe connectors, industrial furnace repair mortar.
\end{abstract}

Keywords: Ceramic fiber, Chamotte, Refractory, Thermal expansion, Thermal shock resistance

*Author for Correspondence: E-mail: mnh_doquang@hcmut.edu.vn and thangnh@hufi.edu.vn

\section{INTRODUCTION}

Refractory materials are types of heat resistant material used as linings for furnaces, hightemperature reactors and others. In addition to being resistant to thermal shocks and physical phenomena caused by heat, refractory materials are also resistant to physical wear and corrosion from chemicals. Refractory materials are more heat-resistant than iron and are required to be applied at high temperatures where other materials are not able to withstand this harsh heat environment [1-3].

Refractory consists of types of materials which have the characteristics of high thermal shock resistance as mentioned above, according to different temperatures, for various time periods, and under different applied conditions. There are many components of refractories manufactured in many different shapes and forms to suit various types of applications. A common feature of refractory materials will be subjected to high temperatures while being repaired. Refractory products are divided into two types: bricks or fired forms and amorphous refractories or specialized materials. Refractory linings are produced from bricks and prefabricated concrete or from specialized refractory materials such as resins, refractory cements, sprayed or compacted mixtures, or a combination of both $[4,5]$.

Many refractory products have similar shapes to traditional building bricks. However, there are many different shapes and styles such as some flame retardant materials are smaller and maybe have complex and sophisticated shapes; 
others are large and can weigh tons in the form of prefabricated blocks [2, 5-8].

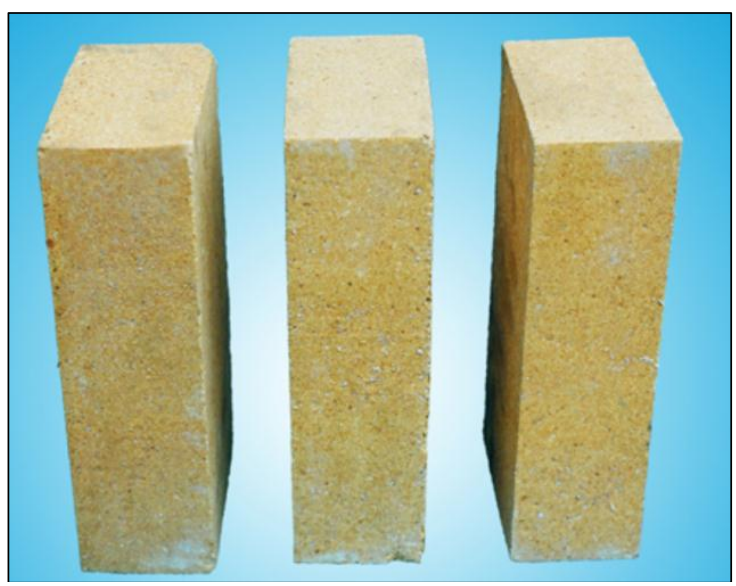

Fig. 1: High Alumina Refractory Brick.

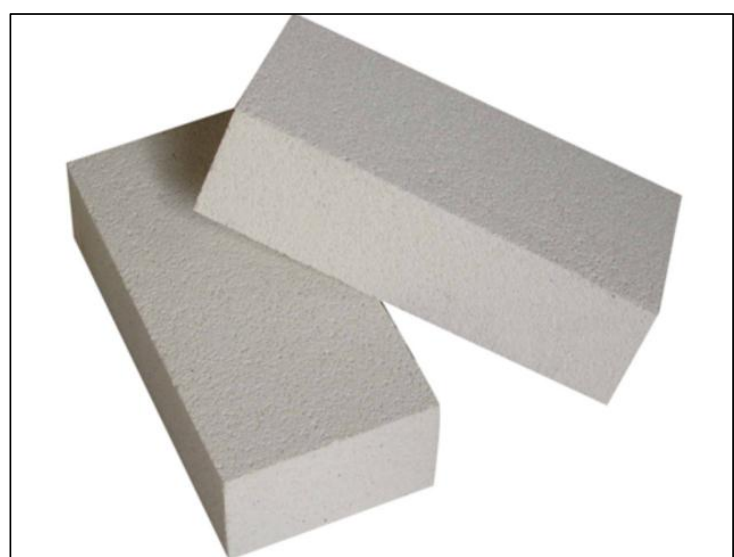

Fig. 2: Porous Insulation Bricks.

Refractories are materials capable of retaining its properties at high temperature. They have a non-metallic main components with combinations of minerals known as alumina, fireclays, bauxite, chromite, dolomite, magnesite, silicon carbide, zirconia, and others. Refractories must have responses the basic requirements: high thermal shock resistance, inertness in chemical reactions and coefficient of thermal expansion within the permissible range of high temperatures [9-11].

Conventional refractories are classified into three main groups, which are acidic refractories, basic refractories, and neutral refractories.

Chamotte refractory materials are manufactured from chamotte stone with refractory clay and fired at high temperatures of $1450^{\circ} \mathrm{C}$. Tests of thermal shock resistance of the chamotte refractory showed that it has around 30 times before destroyed. The processes are carried out at $950^{\circ} \mathrm{C}$ for 1 hour and then put in cold water.

Ceramic wool is a kind of product made of ceramic fiber, in rolls, able to insulate at high temperatures from $1260^{\circ} \mathrm{C}$ to $1430^{\circ} \mathrm{C}$. Ceramic fiber has special uses for kilns, ceramic furnaces. Steel furnaces, kilns of ceramic tiles, food ovens, fireproof windows. Ceramic wool is manufactured to serve thermal insulation projects at high temperature or exposure to fire up to $1600^{\circ} \mathrm{C}$.

Ceramic fibres are low thermal absorption and conductivity, more flexible and high compressive strength, accurate size with high flatness, homogeneous structure, easy to apply and repair, high chemical resistance and heat resistance [11-14].

Ceramic fibers are small sized fibers made from oxides such as $\mathrm{Al}_{2} \mathrm{O}_{3}, \mathrm{SiO}_{2}$, and $\mathrm{ZrO}_{2}$, with high thermal shock resistance [12]. Therefore, the combination of waste ceramic fibers and chamotte refractory aims to improve the thermal endurance of these materials $[3,4]$. Moreover, this is also the solution for environmental treatment caused by the waste ceramic fibers.

\section{MATERIALS AND METHODOLOGY}

Raw materials are Trai Mat chamotte (Lam Dong province, Viet Nam), Tan Uyen clay (Binh Duong province, Viet Nam), ceramic fiber from Isowool company, and $\mathrm{Al}(\mathrm{OH}) 3$ from Tan Rai bauxite factory (Lam Dong province, Viet Nam). Raw meals were mixed from chamotte with particle sizes around 1$2 \mathrm{~mm}$, ceramic fiber, clay, $\mathrm{Al}(\mathrm{OH})_{3}$, and $30 \%$ water. The various ratios among raw materials are shown in Table 1.

Table 1: Ratios of the Raw Materials in the Experimental Mixtures.

\begin{tabular}{|l|c|c|c|c|c|c|}
\hline \multirow{2}{*}{\multicolumn{1}{c|}{ Raw materials }} & \multicolumn{6}{|c|}{ Sample } \\
\cline { 2 - 7 } & $\mathbf{S}_{\mathbf{0}}$ & $\mathbf{S}_{\mathbf{5}}$ & $\mathbf{S}_{\mathbf{1 0}}$ & $\mathbf{S}_{\mathbf{1 5}}$ & $\mathbf{S}_{\mathbf{2 0}}$ & $\mathbf{S}_{\mathbf{2 5}}$ \\
\hline Tan Uyen clay & 18 & 18 & 18 & 18 & 18 & 18 \\
\hline Chamotte & 80 & 75 & 70 & 65 & 60 & 55 \\
\hline $\mathrm{Al}(\mathrm{OH})_{3}$ & 2 & 2 & 2 & 2 & 2 & 2 \\
\hline Ceramic Fiber & 0 & 5 & 10 & 15 & 20 & 25 \\
\hline
\end{tabular}


The mixtures were then formed in the cylindrical samples with a diameter of $80 \mathrm{~mm}$ and height of $100 \mathrm{~mm}$. The samples were heated at $1220^{\circ} \mathrm{C}$ for 1 hour to refractory composite products. Finally, the refractory specimens were tested engineering and thermal properties. In which, the thermal shock resistance was carried out by the number of times the sample heated at $950^{\circ} \mathrm{C}$ and cooled in cold water without broken.

Samples with the best thermal shock resistance were selected for characteristics of microstructure and thermal properties using SEM (scanning electron microscopy), thermal analysis (DTA-TG), and coefficient of thermal expansion (DIL-dilatometer). Evaluation of characteristics among the samples was carried out to have conclusions about the role of ceramic fibers in the refractory composite materials.

Thermal stress $\delta$ in a material is usually calculated by the formula [5]:

$\delta=\mathrm{E} . \alpha \cdot \Delta \mathrm{T}(1)$

In which,

E - modulus of elasticity

$\alpha$ - coefficient of thermal expansion $\left(1 /{ }^{\circ} \mathrm{C}\right)$

$\Delta \mathrm{T}$ - Temperature difference $\left({ }^{\circ} \mathrm{C}\right)$

The above formula shows that the thermal stress will be decreased in case of material haslow the coefficient of thermal expansion. It means that refractory composites must be increased the values of thermal shock resistance.

\section{RESULTS AND DISCUSSION}

In this section experimental results are discussed and analyzed. The section describes properties of raw materials, engineering properties of the refractory composites and coefficient of thermal expansion and several refractory samples for application.

\section{Properties of Raw Materials}

For isowool ceramic fiber1400, it has diameter at $2.8 \mu \mathrm{m}$, a length of $250 \mu \mathrm{m}$, and specific gravity of $2.8 \mathrm{~g} / \mathrm{cm}^{3}$. Trai Mat kaolin was characterized for thermal analysis (DTA-TG) from room temperature to $1220^{\circ} \mathrm{C}$ to obtain Trai Mat chamotte as shown in Figure 3.

Figure 3 shows that total mass change of the kaolin sample is around $10.8 \%$ including values of water content and loss on ignition. The mass loss is related to physico-chemical reactions of clay minerals at different temperatures known as follows:

From room temperature to $200^{\circ} \mathrm{C}$ : water vaporization of the kaolin sample;

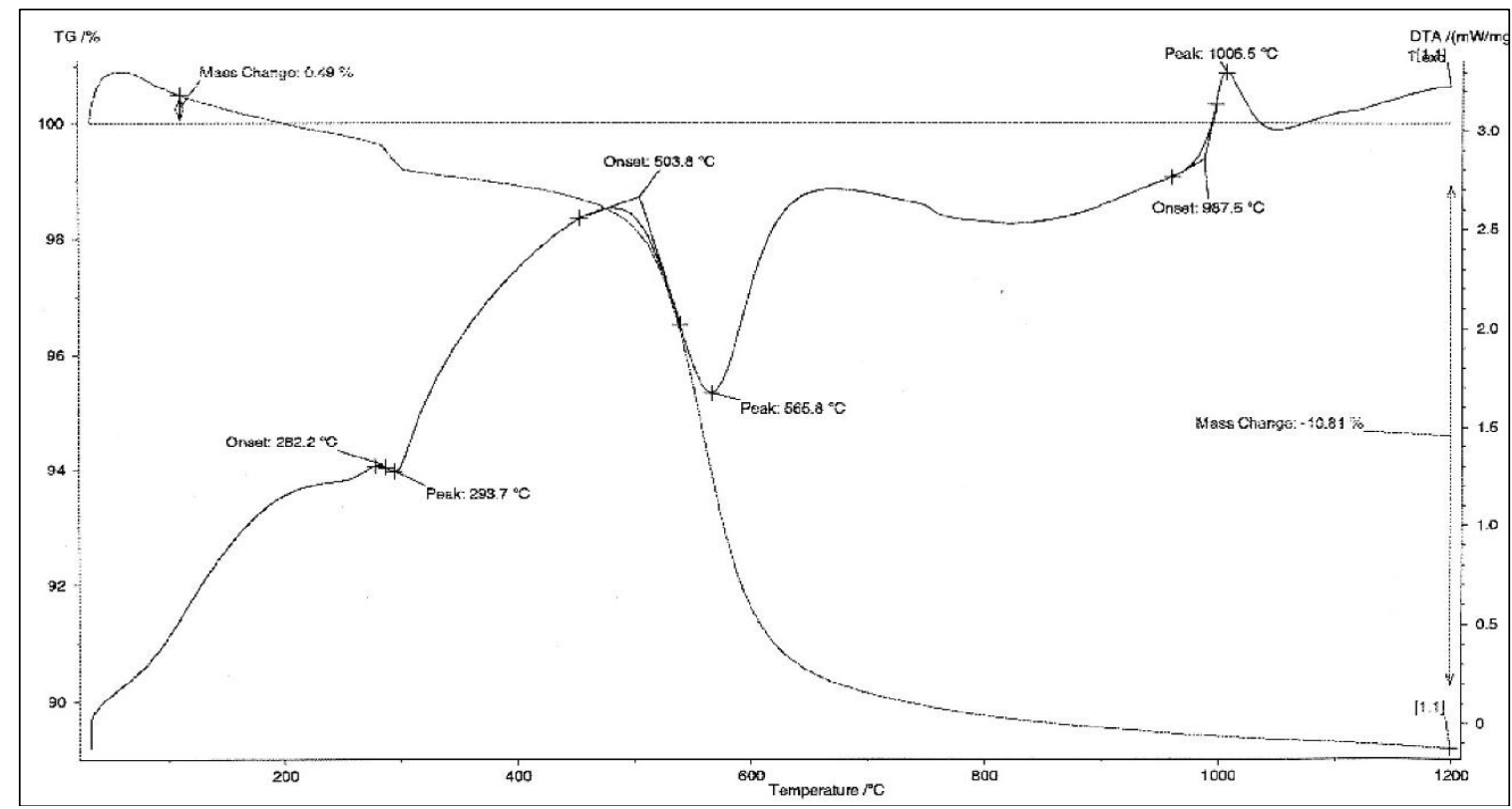

Fig. 3: Physico-chemical Reactions of Trai Mat kaolin to form Chamotte Sand using DTA-TG. 
From $200^{\circ} \mathrm{C}$ to $400^{\circ} \mathrm{C}$ : remaining water vaporization and decomposition of organic matter, especially at $282^{\circ} \mathrm{C}$ and $293^{\circ} \mathrm{C}$;

At $565^{\circ} \mathrm{C}$, the kaolin sample has endothermic reactions with dehydroxylization of clay minerals in kaolin known as kaolinite change into metakaolinite $\left(\mathrm{Al}_{2} \mathrm{O}_{3} \cdot 2 \mathrm{SiO}_{2}\right)$ in the following reaction:

$$
\mathrm{A}_{2} \mathrm{O}_{3} \cdot 2 \mathrm{SiO}_{2} \cdot 2 \mathrm{H}_{2} \mathrm{O} \rightarrow \mathrm{Al}_{2} \mathrm{O}_{3} \cdot 2 \mathrm{SiO}_{2}+2 \mathrm{H}_{2} \mathrm{O}
$$

At $1006^{\circ} \mathrm{C}$, the crystalline products were formed from this amorphous intermediate phase with a prominent exothermic reaction. In this case mullite $\left(3 \mathrm{Al}_{2} \mathrm{O}_{3} \cdot 2 \mathrm{SiO}_{2}\right)$ crystals appeared with phase transition reaction from metakaolinite:

$3\left(\mathrm{Al}_{2} \mathrm{O}_{3} \cdot 2 \mathrm{SiO}_{2}\right) \rightarrow 3 \mathrm{Al}_{2} \mathrm{O}_{3} \cdot 2 \mathrm{SiO}_{2}+4 \mathrm{SiO}_{2}$

The crystals of mullite $\left(3 \mathrm{Al}_{2} \mathrm{O}_{3} \cdot 2 \mathrm{SiO}_{2}\right)$ and quartz $\left(\mathrm{SiO}_{2}\right)$ were detected bythe XRD pattern of Trai Mat chamotte sand sample which heated at $1220^{\circ} \mathrm{C}$ for 1 hour (Figure 4)

The raw materials (Tan Uyen clay, Trai Mat chamotte, Isowool ceramic fiber) were tested for chemical composition using a method of $x$ ray fluorescence (XRF). The results in Table 2 show that the raw materials contain high silica and aluminum oxides from 49.7 to $64.1 \%$ and 22.9 to $44.1 \%$, respectively. In addition, isowool ceramic fiber also has $15.0 \% \mathrm{ZrO}_{2}$, Trai Mat chamotte has no value of loss on ignition (L.O.I) while Tan Uyen clay contains high value of L.O.I at $6.7 \%$.

Table 2: Chemical Compositions of Raw Materials (\% wt.)

\begin{tabular}{|l|c|c|c|}
\hline Oxides & $\begin{array}{c}\text { Tan Uyen } \\
\text { clay }\end{array}$ & $\begin{array}{c}\text { Trai Mat } \\
\text { chamotte }\end{array}$ & $\begin{array}{c}\text { Isowool ceramic } \\
\text { fiber1400 }\end{array}$ \\
\hline $\mathrm{SiO}_{2}$ & 64.1 & 52.7 & 49.7 \\
\hline $\mathrm{Al}_{2} \mathrm{O}_{3}$ & 22.9 & 44.1 & 35.0 \\
\hline $\mathrm{Fe}_{2} \mathrm{O}_{3}$ & 0.9 & 1.5 & 0 \\
\hline $\mathrm{K}_{2} \mathrm{O}$ & 2.8 & 1.1 & - \\
\hline $\mathrm{ZrO}_{2}$ & 0 & 0 & 15.0 \\
\hline $\mathrm{L} . \mathrm{O} . \mathrm{I}$ & 6.7 & 0 & 0 \\
\hline
\end{tabular}

\section{Engineering Properties of The Refractory Composites}

The refractory samples were prepared with ratios of raw materials as mentioned in Table 1 and heated at $1220^{\circ} \mathrm{C}$ for 1 hour. The specimens then were tested for engineering properties such as volumetric weight $(\gamma$, $\left.\mathrm{g} / \mathrm{cm}^{3}\right)$, compressive strength $\left(\mathrm{R}_{\mathrm{CS}}, \mathrm{MPa}\right)$, bending strength $\left(\mathrm{R}_{\mathrm{BS}}\right.$, MPa) and thermal shock resistance (times). The experimental results are shown in Tables 3 and 4.

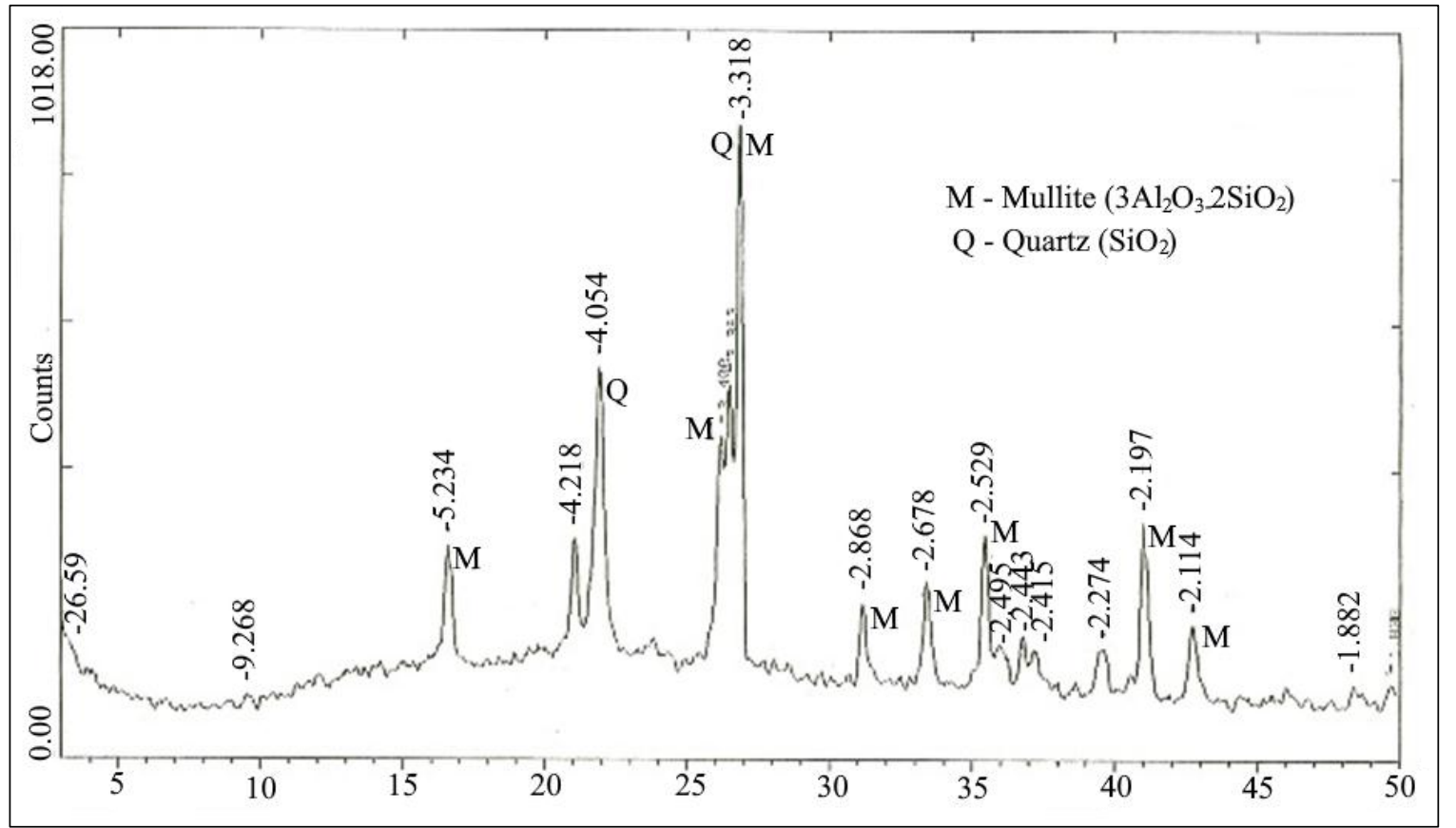

Fig. 4: Crystals of Mullite $(M)$ and Quartz $(Q)$ in Phase Compositions of Trai Mat Chamottesand after Fired at $1220^{\circ} \mathrm{C}$ for 1 Hour. 
Table 3:Volumetric Weight and Thermal Shock Resistance of the Refractory Composites.

\begin{tabular}{|l|c|c|}
\hline Samples & $\begin{array}{c}\text { Volumetric weight, } \boldsymbol{\gamma} \\
\left(\mathbf{g} / \mathbf{c m}^{\mathbf{3}}\right)\end{array}$ & $\begin{array}{c}\text { Thermal shock } \\
\text { resistance (Times) }\end{array}$ \\
\hline $\mathbf{S}_{\mathbf{0}}$ & 0.87 & $>30$ \\
\hline $\mathbf{S}_{\mathbf{5}}$ & 1.32 & $>30$ \\
\hline $\mathbf{S}_{\mathbf{1 0}}$ & 1.06 & 50 \\
\hline $\mathbf{S}_{\mathbf{1 5}}$ & 1.06 & 50 \\
\hline $\mathbf{S}_{\mathbf{2 0}}$ & 1.03 & 50 \\
\hline $\mathbf{S}_{\mathbf{2 5}}$ & 1.00 & 50 \\
\hline
\end{tabular}

Table 4: The Strength Values of the Refractory Composites.

\begin{tabular}{|l|c|c|}
\hline Samples & $\begin{array}{c}\text { Bending strength } \\
\mathbf{R}_{\mathbf{B S}}(\mathbf{M P a})\end{array}$ & $\begin{array}{c}\text { Compressive strength } \\
\mathbf{R}_{\mathbf{C S}}(\mathbf{M P a})\end{array}$ \\
\hline $\mathbf{S}_{\mathbf{0}}$ & 3.09 & 27.24 \\
\hline $\mathbf{S}_{\mathbf{5}}$ & 7.10 & 54.61 \\
\hline $\mathbf{S}_{\mathbf{1 0}}$ & 36.06 & 96.58 \\
\hline $\mathbf{S}_{\mathbf{1 5}}$ & 44.58 & 145.11 \\
\hline $\mathbf{S}_{\mathbf{2 0}}$ & 32.75 & 72.24 \\
\hline $\mathbf{S}_{\mathbf{2 5}}$ & 30.26 & 63.66 \\
\hline
\end{tabular}

For volumetric weight, the refractory samples have low values from 0.87 to 1.32 $\mathrm{g} / \mathrm{cm}^{3}$. In which, the $\mathrm{S}_{5}$ sample is the heaviest material at $1.32 \mathrm{~g} / \mathrm{cm}^{3}$ and others samples are around $1.00 \mathrm{~g} / \mathrm{cm}^{3}$. For thermal shock resistance, the refractory composites have high values upto 50 time except for samples $S_{0}$ and $S_{5}$ less than 30 times because of containing low isowool ceramic fiber1400. It is noted that the samples with over $10 \%$ isowool ceramic fiber1400 have the values of thermal shock resistance more than 50 times.

For strength, the refractory specimens have bending strength from 3.09 to $44.58 \mathrm{MPa}$ with the lowest values of the sample $S_{0}$ contained $0 \%$ isowool ceramic fiber. The sample $S_{15}$ with $15 \%$ isowool ceramic fiber has the highest values of bending strength and compressive strength of 44.58 and 145.11 $\mathrm{MPa}$, respectively. The refractory specimens have a compressive strength from 27.24 to 145.11 MPa. Development of the strength in the refractory samples related to the sintering process of ceramics at high temperature. The samples with high isowool ceramic fiber $\left(S_{20}\right.$ and $S_{25}$ ) were decreased the strength values because ceramic fibers with a high content inhibited the diffusion and sintering reaction of the solid powders in the mixtures.

Figures 6 and 7 are microstructure of the refractory samples $S_{0}$ and $S_{15}$ with ceramic fibers rodsand solid phases. The structure of the sample $S_{0}$ is background of solid phase particles while the sample $S_{15}$ contains the ceramic fiberrods bonded to surrounding solid phase particles. The rod structures inhibited the development of micro-cracks in the refractory chamotte materials, which improving the mechanical and thermal properties of the sample $S_{15}$.

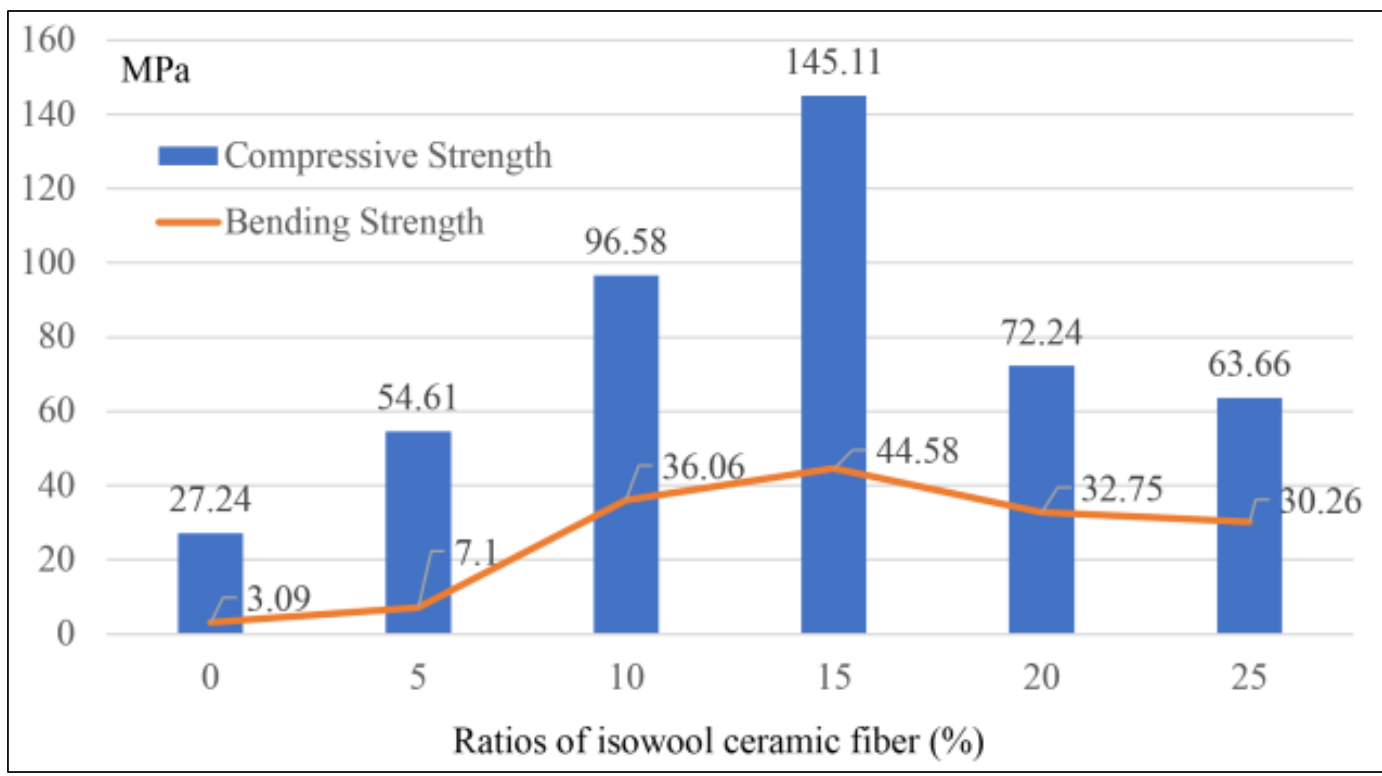

Fig. 5: Compressive and Bending Strength (MPa) of the Refractory Composite Materials Produced from Chamotte Sand and Ceramic Fiber. 


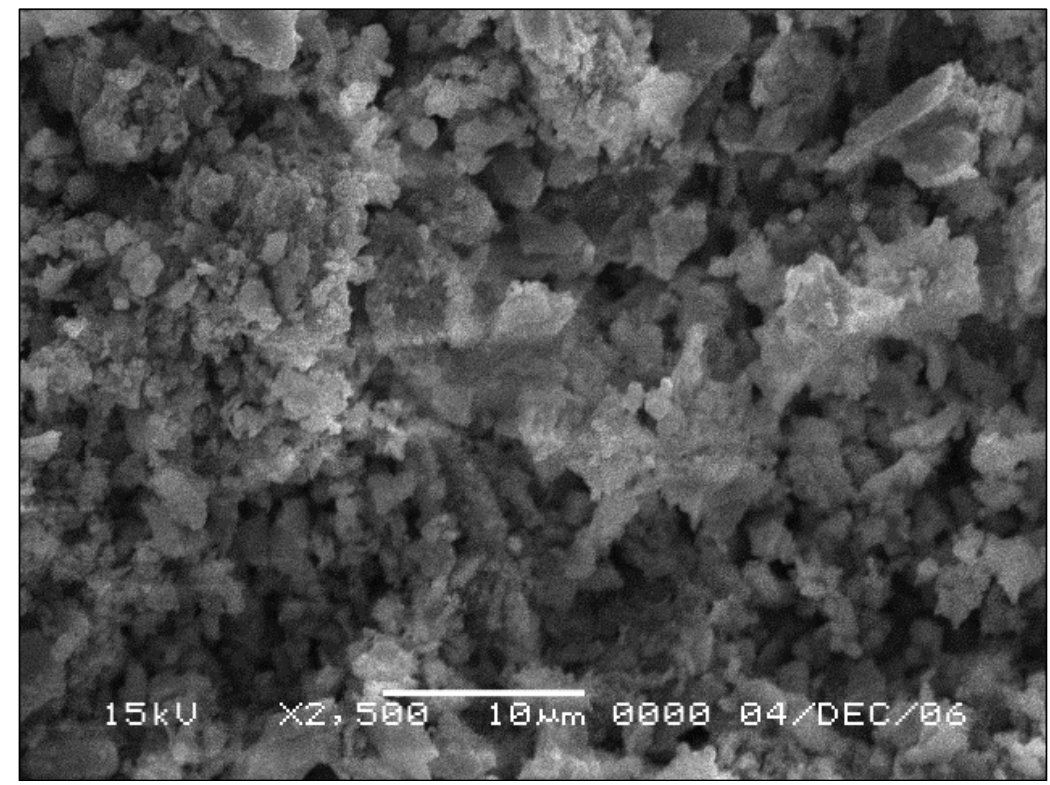

Fig. 6: Microstructure of the Refractory Samples $S_{0 .}$

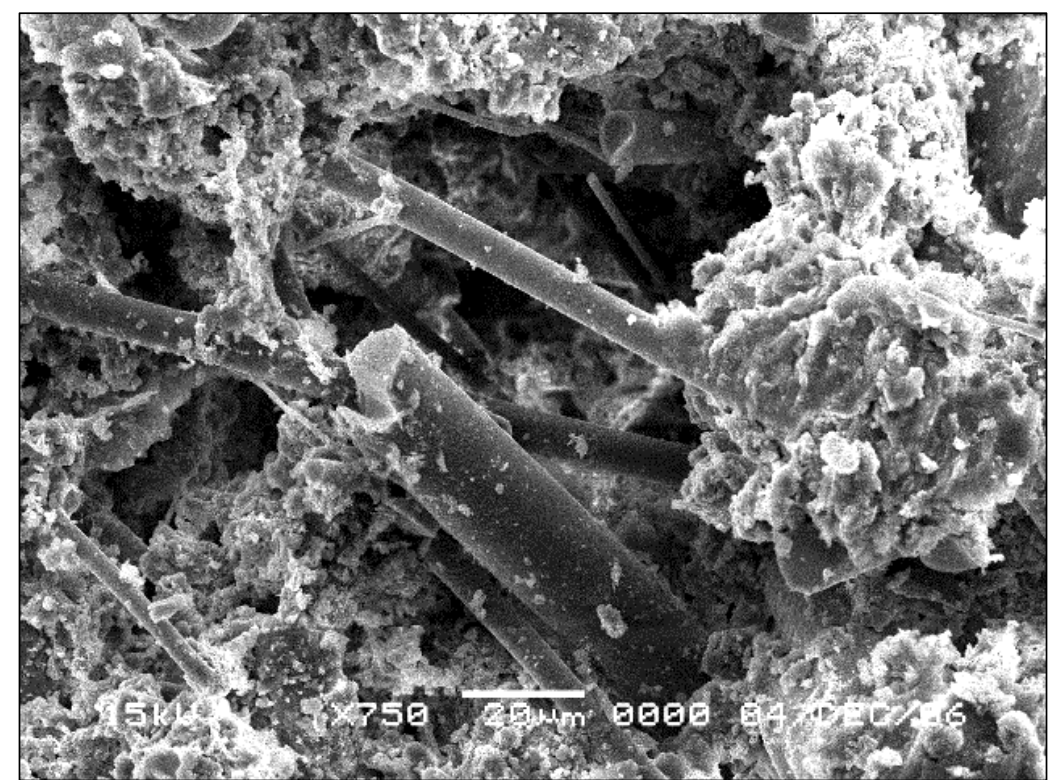

Fig. 7: Microstructure of the Refractory Samples $S_{15}$.

Coefficient of Thermal Expansion and Several Refractory Samples for Application The refractory samples of $S_{0}$ and $S_{15}$ were also characterized for coefficient of thermal expansion using Dilatometerwith the results as shown in Figures 8 and 9.

The coefficient of thermal expansion in Figures 8 and 9 are determined by the linear equation:

$y=a x+b$

In this equation,
$y=\Delta L / L_{0}$ is length decrease of the sample compared to the original length $\mathrm{L}_{0}$, $x$ is temperature $\left({ }^{\circ} \mathrm{C}\right)$,

$a$ and $b$ are experimental coefficients.

Both the refractory samples of $S_{0}$ and $S_{15}$ have the coefficient of thermal expansion with linear lines divided into 3 parts related to thermal changes of phases in the refractory composites. It was based on the values from Figures 8 and 9, the linear equations (y) are determined in the ranges of the various temperature as follows: 


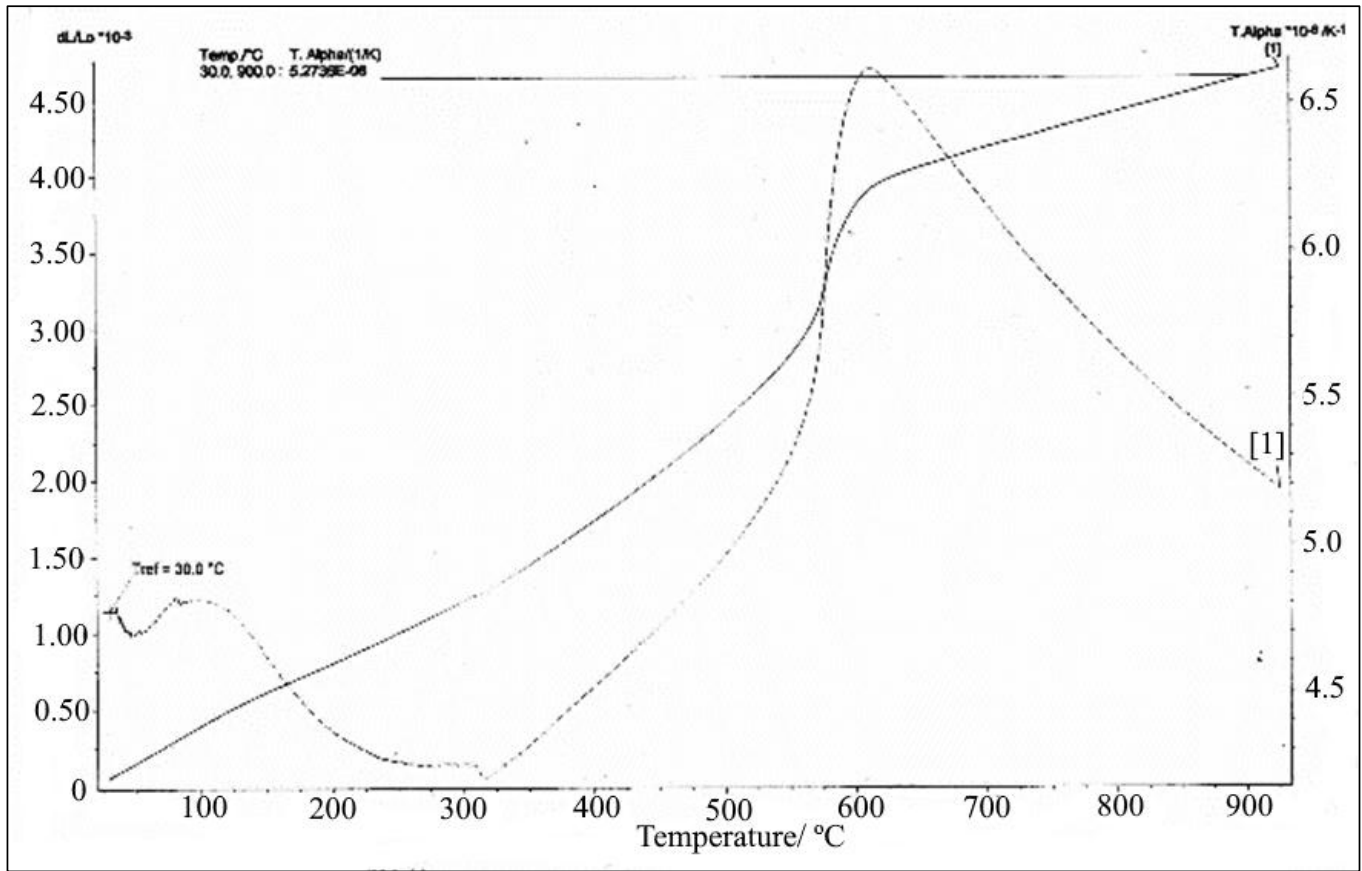

Fig. 8: The Coefficientof Thermal Expansion of the Refractory Composite without Isowool Ceramic Fiber ( sample $S_{0}$ ).

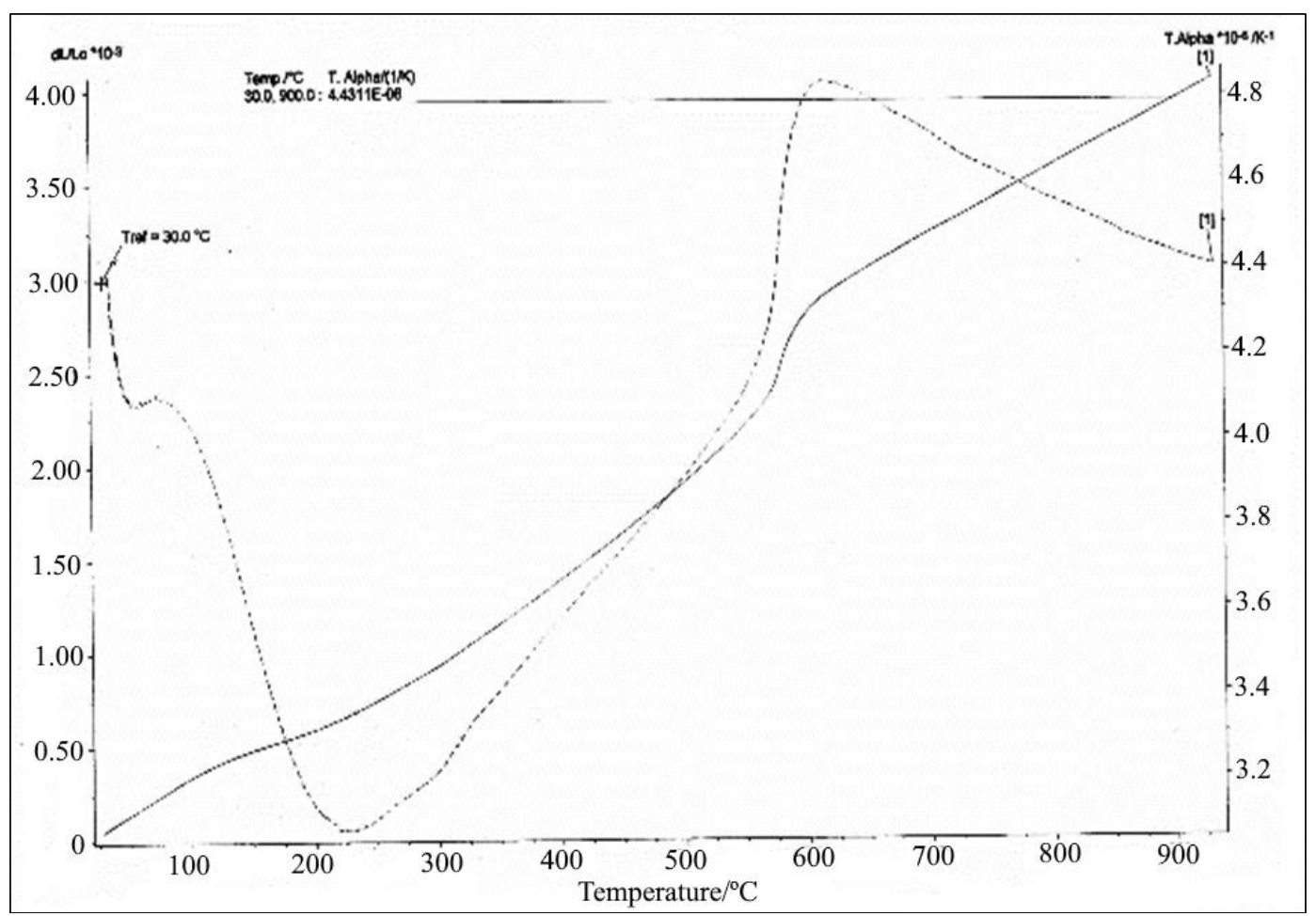

Fig. 9: The Coefficientof Thermal Expansion of the Refractory Composite with 15\% Isowool Ceramic Fiber ( sample $S_{15}$ ).

From room temperature to $560^{\circ} \mathrm{C}$, the equations for coefficients of thermal expansion of the samples

$\mathrm{S}_{0}: y=[0.00437 \cdot x+2.83076] \cdot 10^{-6}\left(1 /^{\circ} \mathrm{C}\right)$
$\mathrm{S}_{15}: y=[0.00334 \cdot x+2.31466] \cdot 10^{-6}\left(1 /^{\circ} \mathrm{C}\right)$

From $560^{\circ} \mathrm{C}$ to $610^{\circ} \mathrm{C}$, both of the samples have phase structural transform of the quartz crystals $\left(\mathrm{SiO}_{2}\right)$ in the refractory composites: 
$\beta$-quartz $\leftrightarrow$-quartz

From $610^{\circ} \mathrm{C}$ to $950^{\circ} \mathrm{C}$, the equations for coefficients of thermal expansion of the samples

$\mathrm{S}_{0}: y=[0.00469 . x+9.42050] \cdot 10^{-6}\left(1 \rho^{\rho} C\right)$

$\mathrm{S}_{15}: y=y=[0.00140 \cdot x+5.68986] \cdot 10^{-6}\left(1 \rho^{\rho} \mathrm{C}\right)$

The coefficient of thermal expansion of the sample $S_{15}$ is lower than that of the sample $S_{0}$.This leads tothe thermal stress Sofsample $\mathrm{S}_{15}$ islower and thatis also the reason which the sample $S_{15}$ hashigh thermal shock resistance than the sample $S_{0}$.

The investigation was carried out production of several refractory samples applied in furnace as shown in Figure 10.

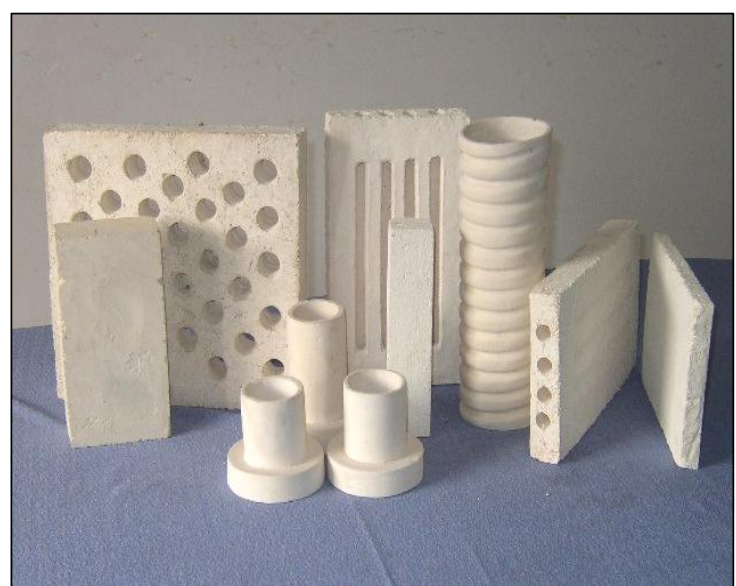

Fig. 10: Some Practical Applications of the Refractory Composites from Waste Ceramic Fiber and Chamotte Material.

\section{CONCLUSION}

Refractory composite materials are applied in many fields with the different production technology. This study used isowool ceramic fibers, Tan Uyen clay, and Trai Mat chamotte sand for producing the refractory. These refractory composites are fired at a relatively low temperature $\left(1220^{\circ} \mathrm{C}\right)$, but its quality is still guaranteed for thermal shock resistance. The ceramic fibers created bonding networks in the chamotte background to increase the thermal shock resistance and the strength.Besides, the fiber rods prevented the development of microcracks in the material. Therefore, the waste ceramic fiber should be used as a raw material to producerefractorymaterials. This will contribute to reduce the emissions of ceramic fibers causing environmental pollution.

\section{Nomenclature}

$\delta \quad:$ Thermal Stress

E : Modulus of Elasticity

$\alpha \quad: \quad$ Coefficient of Thermal Expansion

$\Delta \mathrm{T} \quad$ : Temperature Variation

DTA : Differential Thermal Analysis

XRD : X-Ray Diffraction

L.O.I : Loss On Ignition

SEM : Scanning Electron Microscopy

\section{REFERENCES}

1. EijiHorie, Ceramic fibre insulation theory and practice-The energy conservation center, Tokyo, 1997.

2. Černý, R., Poděbradská, J., Toman, J., Jiříčková, M., Mňahončáková, E., Rovnaníková, P., Bayer, P., High Temperature Properties of Fibre Reinforced Cement Composites, Proceedings of the International Conference on Application of Codes, Design and Regulations, 2005, 403-412.

3. Holčapek, O., Reiterman, P., Konvalinka, P., Fracture Characteristics of Refractory Composites Containing Metakaolin and Ceramic Fibers, Advances in Mechanical Engineering, 2015, 7(3), 1-13.

4. Ondřej, H., Jaroslava, K., Pavel, R., Fiber Reinforced Concrete with Application in Civil Engineering,Advances in Civil Engineering, 2018, 2018,1-11.

5. Kingery, W.D., Bowen,H.K., Uhlmann, D.R.,Introduction to Ceramic, $2^{\text {nd }}$ edition, Wiley, 1976.

6. Groover, P. Mikell, Fundamentals of Modern Manufacturing: Materials, Processes, and Systems, John Wiley \& Sons, 2010.

7. Deer, W.A., Howie, R.A., Zussman, J., An introduction to the rock-forming minerals, 2nd edition, Harlow: Longman, 1992.

8. Káosek-Wawrzyn, E., Maáolepszy, J., Murzyn, P., Sintering Behavior of Kaolin with Calcite, Procedia Engineering, 2013, $57,572-582$.

9. Mohtor, N.H., Othman, M.H.D., Ismail, A.F., Rahman, M.A., Jaafar, J., Hashim, N.A., Investigation on the effect 
of sintering temperature on kaolin hollow fibre membrane for dye filtration, Environmentalscienceand pollutionresearch, 2017, 24, 1590515917.

10. Do, Q.M., Nguyen, T.T.L., Pham, V.T.H.Q., Nguyen, H.T., The Novel Crystalline Glaze for Decoration of Ceramic Pottery, Materials science forum, 2020, 987, 165-170.

11. Ravichandran, G.,Halloysite nanotubes-A novel reinforcing material for future applications, Journal of polymer and composites, 2019, 7(1), 34-40.

12. Patnaik, S.C., Maharana,S., Adak, S., Mishra, A.,A Study on the Sintering Behavior of $\mathrm{Al}_{2} \mathrm{O}_{3} / \mathrm{Y}_{2} \mathrm{O}_{3}$ Doped $\mathrm{ZrO}_{2}$ Composites, Journal of polymer and composites, 2014, 2(1), 1-8.

13. Nguyen, H.T., Gallardo, S.M., Bacani, F.T., Hirofumi Hinode, Do, .M., Do, M.H., Promentilla, M.A.B., Evaluating thermal properties of geopolymer produced from red mud, rice husk ash and diatomaceous earth, ASEAN engineering journal, 2015, 4(1) 51-65.

14. Nguyen, H.T., Pham, T.K., Abdullah, M.M.A.B., Lightweight heat resistant geopolymer-based materials synthesized from red mud and rice husk ash using sodium silicate solution as alkaline activator, MATEC Web of Conferences, 2017, 97, 01119.

\section{Cite this Article}

Do Quang Minh, Nguyen Vu Uyen Nhi, Nguyen Hoc Thang. Development of Refractory Synthesized from Waste Ceramic Fiber and Chamotte. Journal of Polymer \& Composites. 2020; 8(2): 101-109p. 